\title{
Primary replication and invasion of the bovine gammaherpesvirus BoHV-4 in the genital mucosae
}

\author{
Bo Yang ${ }^{1,2}$, Yewei Li ${ }^{1}$, Osvaldo Bogado Pascottini ${ }^{2}$, Jiexiong Xie ${ }^{1}$, Ruifang Wei ${ }^{1}$, Geert Opsomer ${ }^{2}$ \\ and Hans Nauwynck ${ }^{1 *}$
}

\begin{abstract}
Bovine herpesvirus 4 (BoHV-4) is a gammaherpesvirus that is widespread in cattle. Ex vivo models with bovine genital tract mucosa explants were set up to study molecular/cellular BoHV-4-host interactions. Bovine posterior vagina, cervix and uterus body were collected from cows at two stages of the reproductive cycle for making mucosa explants. The BoHV-4 replication kinetics and characteristics within the three different mucosae of animals in the follicular and luteal phase were assessed by virus titration. The number of plaques, plaque latitude and number of infected cells were determined by immunofluorescence. BoHV-4 replicated in a productive way in all genital mucosal tissues. It infected single individual cells in both epithelium and lamina propria of the genital mucosae at 24 hours post-inoculation (hpi). Later, small BoHV-4 epithelial plaques were formed that did not spread through the basement membrane. $50 \%$ of the number of BoHV-4 infected cells were identified as cytokeratin ${ }^{+}$and $\mathrm{CD} 172 \mathrm{a}^{+}$cells in the three parts of the genital tract at $24 \mathrm{hpi}$. Upon a direct injection of genital explants with BoHV-4, fibrocytes became infected, indicating that the unidentified $50 \%$ of the infected cells are most probably fibrocytes. In this study, in vivo-related in vitro genital tract models were successfully established and the early stage of the pathogenesis of a genital infection was clarified: BoHV-4 starts with a productive infection of epithelial cells in the reproductive tract, forming small foci followed by a non-productive infection of surveilling monocytic cells which help BoHV-4 to invade into deeper tissues.
\end{abstract}

\section{Introduction}

Bovine herpesvirus 4 (BoHV-4) is a gammaherpesvirus belonging to the genus rhadinovirus. It has been related with several diseases in cattle. BoHV-4 was first isolated from bovine with respiratory problems and keratoconjunctivitis in 1963 in Hungary [1]. Since then, the virus has been isolated from cattle with respiratory disease, conjunctivitis, metritis, ulcerative mammillitis, dermatitis and abortion in Europe, North America, Africa and Asia [2-6]. However, it has also been isolated from healthy cattle [7]. Up till now, little is known on how BoHV-4 may cause disease in bovine.

\footnotetext{
*Correspondence: hans.nauwynck@ugent.be

1 Department of Virology, Parasitology and Immunology, Faculty

of Veterinary Medicine, Ghent University, Salisburylaan 133,

B-9820 Merelbeke, Belgium

Full list of author information is available at the end of the article
}

Uterine infections can cause significant economic losses in cattle industry. Although most causative agents have been identified as bacteria, BoHV-4 has been considered as a possible (co-)factor in post-partum metritis [8]. BoHV-4 is widespread in bovine and remains latent and asymptomatic in the vast majority of infected individuals. BoHV-4 persists mainly in peripheral blood leukocytes, the nervous system and lymphoid organs $[9,10]$. Until now, a lot of work has been done to acquire more information on the viral molecular biology of BoHV4. There are some reports on viral entry [11-13] and immune evasion [14] of BoHV-4. In addition, the construction of a BoHV-4 bacterial artificial chromosome (BAC) has provided an efficient tool for the study of the viral molecular biology of BoHV-4 [15-19]. Jacca et al. forwarded a hypothesis about the pathogenesis of BoHV4: bovine macrophages are latently infected with BoHV-4 and upon reactivation, bystander endometrial stromal 
cells become infected [21]. This replication in the endometrium may cause inflammation. Once there, BoHV-4 might initiate replication within macrophages and spread to endometrial stromal cells, which are highly susceptible for BoHV-4 [20, 21]. However, data concerning the early pathogenesis of BoHV-4 at the genital tract are scarce. One of the biggest obstacles in getting better insights is the lack of in vivo-related in vitro models. Therefore, we developed in vitro models to examine the early BoHV-4 replication in the genital tract.

\section{Materials and methods}

\section{Virus strain}

The BoHV-4 strain V.test was used in this study, which belongs to the European clade of BoHV-4 strains. It was originally isolated from an infertile bull's testicle [17]. The strain V.test had previously received an unknown number of passages. The virus was passaged two times in MadinDarby Bovine Kidney (MDBK) cells in our laboratory.

\section{Animals}

Healthy genital tissues (posterior vagina, cervix and uterus body) from cows of 2-4 years old were collected in a local slaughterhouse. In addition, blood was collected to determine BoHV-4 specific neutralizing antibodies with a complement-dependent seroneutralization (SN)-test and blood progesterone (P4). The stage of the reproductive cycle was determined by a morphological analysis of the ovaries and the blood progesterone (P4) level.

\section{Preparation of air-liquid interface tissue culture}

From three cows in the luteal phase and three cows in the follicular phase, posterior vagina, cervix and uterus body were collected at the local abattoir immediately after slaughter. The cultivation protocol of bovine genital mucosa was performed as described before [22-24]. In brief, genital tissues of cows were immediately placed in phosphate buffered saline (PBS), supplemented with $1000 \mathrm{U} / \mathrm{mL}$ penicillin (Continental Pharma, Puurs, Belgium), $1 \mathrm{mg} / \mathrm{mL}$ streptomycin (Certa, Braine l'Alleud, Belgium), $1 \mu \mathrm{g} / \mathrm{mL}$ gentamycin (Invitrogen, Paisley, UK) and $5 \mu \mathrm{g} / \mathrm{mL}$ fungizone (Bristol-Myers Squibb, New York, USA) on ice for transportation to the laboratory. The mucosae from vagina, cervix and uterus body were stripped from the underlying layers. Afterwards, tissues were cut into small equal square pieces (on average $25 \mathrm{~mm}^{2}$ ). Finally, genital mucosa was placed on sterilized gauzes in 6-well plates for culture. The explants were cultured in serum-free medium [50\% DMEM (Invitrogen) $/ 50 \%$ Ham's F-12 Gluta-MAX (Invitrogen)], supplemented with $100 \mathrm{U} / \mathrm{mL}$ penicillin (Continental Pharma), $0.1 \mathrm{mg} / \mathrm{mL}$ streptomycin (Certa) and $1 \mu \mathrm{g} / \mathrm{mL}$ gentamycin (Invitrogen) for up to $96 \mathrm{~h}\left(37{ }^{\circ} \mathrm{C}\right.$ and $5 \%$ $\left.\mathrm{CO}_{2}\right)$.

\section{Evaluation of tissue viability}

All tissues were monitored by measuring the occurrence of apoptosis to determine the viability during in vitro culture. The In Situ Cell Death Detection Kit (Roche Diagnostics, Switzerland) based on terminal deoxynucleotidyl transferase dUTP nick end-labeling (TUNEL) was used to evaluate the DNA fragmentation. The test was performed according to the manufacturer's guidelines. TUNEL-positive cells were counted from five randomly chosen fields of 100 cells in the epithelium as well as in the lamina propria at $0,24,48,72$ and $96 \mathrm{~h}$ of culture. All stainings were analyzed with a TCS SPE confocal system (Leica Microsystems GmbH, Wetzlar, Germany).

\section{Virus inoculation}

After $24 \mathrm{~h}$ cultivation of explants, the inoculation was performed. Genital explants were taken from their gauze and placed in a 24-well plate. After 2 washings with PBS, explants were either submerged in $0.5 \mathrm{~mL}$ of BoHV-4 containing medium $\left(10^{7} \mathrm{TCID}_{50} / \mathrm{mL}\right)$ and incubated for $1 \mathrm{~h}\left(37^{\circ} \mathrm{C}, 5 \% \mathrm{CO}_{2}\right)$ or mock inoculated. Before explants were placed back on the gauze, they were washed three times with PBS. The inoculated tissues were collected at $0,24,48$ and $72 \mathrm{hpi}$. In addition, explant cultivation medium was also collected for virus titration. All gathered explants were embedded in cryoprotection medium [Methocel ${ }^{\circledR}$, Fluka (Sigma)] and then frozen at $-70{ }^{\circ} \mathrm{C}$.

\section{Replication kinetics of BoHV-4 in the mucosa of different parts of the genital tract Virus titration}

Explant cultivation medium was collected at $0,24,48 \mathrm{~h}$ and 72 hpi from BoHV-4 inoculated and mock inoculated explants for virus titration. Briefly, MDBK cells were inoculated for $1 \mathrm{~h}\left(37{ }^{\circ} \mathrm{C}, 5 \% \mathrm{CO}_{2}\right)$ with serial tenfold dilutions $\left(10^{0}\right.$ to $10^{-7}$ in quadruplicate) of BoHV-4 and mock inoculated explant medium. Afterwards, MDBK cells were observed daily for cytopathic effect (CPE) for 7-9 days.

\section{Evaluation of primary viral replication in the genital mucosae} At $0,24,48 \mathrm{~h}$ and $72 \mathrm{hpi}$, mucosa explants were collected. To evaluate the lateral spread of BoHV-4 in the epithelial cell layer and its penetration in the connective tissue underneath the basement membrane, a double staining was performed. Cryosections $(20 \mu \mathrm{m})$ of the different explants were made, paraformaldehyde fixed for $15 \mathrm{~min}$ at $4{ }^{\circ} \mathrm{C}$ and then permeabilized with PBS containing $0.1 \%$ Triton X-100 (PBST) for 10 min. After three washings, a primary mouse monoclonal IgG2a antibody (Mab35) 
against the glycoprotein complex gp6/gp10/gp17 of BoHV-4 (1:1000 in PBS) was used [25-27]. Next, a secondary goat anti-mouse IgG2a Alexa fluor ${ }^{\circledR} 488$ (Invitrogen) $(4 \mu \mathrm{g} / \mathrm{mL})$ was used. Analyses of IF stainings were performed by TCS SPE confocal system (Leica Microsystems GmbH, Wetzlar, Germany). Thereafter, the plaque latitude was evaluated using the line-tool function of the software program ImageJ.

\section{Quantification and characterization of BoHV-4 infected cells}

In order to identify the single BoHV-4 infected cells early after inoculation, double immunofluorescence stainings were performed using different cell surface markers. At least 20 cryosections $(20 \mu \mathrm{m})$ were made for each marker of both BoHV-4 and mock inoculated genital mucosae. Cryosections were fixed in methanol $\left(-20{ }^{\circ} \mathrm{C}, 100 \%\right)$ for 20 min and washed in PBS. Afterwards, they were incubated with a primary mouse monoclonal IgG2a antibody (Mab35) against BoHV-4 for $1 \mathrm{~h}$ at $37{ }^{\circ} \mathrm{C}$, followed by an incubation with a secondary goat anti-mouse IgG2a Alexa fluor ${ }^{\circledR} 594$ (Invitrogen) $(4 \mu \mathrm{g} / \mathrm{mL})$. Afterwards, a primary monoclonal mouse IgG1 antibody DH59B (VMRD Inc., Pullman) or monoclonal mouse IgG1 antihuman cytokeratin (Dako, Glostrup, Denmark) $(1.72 \mu \mathrm{g} /$ $\mathrm{mL})$ with a secondary goat anti-mouse $\operatorname{IgG} 1 \mathrm{FITC}^{\circledR}$ (Abcam, Cambridge, UK) $(1 \mu \mathrm{g} / \mathrm{mL})$ were used to stain monocytes/macrophages/dendritic or epithelial cells, respectively. A polyclonal sheep anti-bovine IgM labeled with FITC $^{\circledR}$ (AbD Serotec) $(6 \mu \mathrm{g} / \mathrm{mL})$ was used to stain B lymphocytes. A primary monoclonal rat IgG1 antihuman CD3 (AbD Serotec, Biorad-laboratories, Kidlington, UK) $(10 \mu \mathrm{g} / \mathrm{mL})$ and secondary goat anti-rat Alexa fluor $^{\circledR} 488$ (Invitrogen) $(2 \mu \mathrm{g} / \mathrm{mL})$ were used to stain $\mathrm{T}$ lymphocytes. Moreover, a primary monoclonal mouse IgG1 anti-vimentin (AbD Serotec) (1:100 in PBS) with a secondary goat anti-mouse IgG1 FITC ${ }^{\circledR}$ (Abcam, Cambridge, UK) $(1 \mu \mathrm{g} / \mathrm{mL})$ were used to detect cells of mesenchymal origin. All incubation steps were performed at
$37{ }^{\circ} \mathrm{C}$ for $1 \mathrm{~h}$ followed by three washings. Finally, Hoechst 33342 (Invitrogen) $(10 \mu \mathrm{g} / \mathrm{mL})$ was used in the last step to stain cell nuclei at $37^{\circ} \mathrm{C}$ for $10 \mathrm{~min}$. After washing with PBS, the cryosections were mounted with glycerinDABCO and then analyzed by TCS SPE confocal system (Leica Microsystems GmbH, Wetzlar, Germany).

\section{BoHV-4 replication in the genital submucosa upon direct injection}

In order to investigate if fibrocytes can be infected by BoHV-4 in the genital submucosa, a direct injection was performed. Explants were injected with $0.2 \mathrm{~mL}$ containing $2 \times 10^{7}$ TCID $_{50}$ BoHV-4 mixed with $0.2 \mu \mathrm{L}$ carboxylate-modified microspheres [FluoSpheres ${ }^{\circledR}$, $0.2 \mu \mathrm{m}$, red fluorescent [580/605] (Invitrogen no. F8810)] or PBS alone [28]. A $1 \mathrm{~mL}$ syringe and a thin needle $(0.9 \times 25 \mathrm{~mm})$ were used. The explant was further cultured at $37{ }^{\circ} \mathrm{C}$ and then collected at $72 \mathrm{hpi}$. Cryosections $(20 \mu \mathrm{m})$ were made. The above virus staining protocol was used. Analysis was performed by TCS SPE confocal system.

\section{Statistical analysis}

Data were statistically processed by Graphpad Prism 5.0 (GraphPad Software, Inc., San Diego, CA, USA) for analysis of variance (one-way ANOVA). The data are represented as means with standard deviation (SD) of three independent experiments. Results with $P$ values of $\leq 0.05$ were considered significant.

\section{Results}

\section{Tissue viability}

The percentages of TUNEL positive cells in the different tissues at different time points of culture are shown in Table 1. During $96 \mathrm{~h}$ of in vitro culture, no significant changes were found in the occurrence of apoptosis in the epithelium and lamina propria (Additional file 1). The percentage of apoptotic cells in the epithelium of all

Table 1 Occurrence of apoptosis in epithelium and lamina propria as a parameter for the effect of in vitro culture on the viability of bovine genital mucosae explants

\begin{tabular}{|c|c|c|c|c|c|c|}
\hline \multirow[t]{2}{*}{ Tissue } & \multirow[t]{2}{*}{ Layer } & \multicolumn{5}{|c|}{$\%$ of TUNEL-positive cells at ...h of cultivation } \\
\hline & & 0 & 24 & 48 & 72 & 96 \\
\hline \multirow[t]{2}{*}{ Vagina } & Epithelium & $0.8 \pm 0.8$ & $1.0 \pm 0.7$ & $1.4 \pm 1.3$ & $1.8 \pm 1.3$ & $2.0 \pm 1.6$ \\
\hline & L. propria & $1.2 \pm 0.8$ & $2.6 \pm 1.8$ & $4.0 \pm 1.6$ & $5.4 \pm 2.1$ & $7.8 \pm 2.4$ \\
\hline \multirow[t]{2}{*}{ Cervix } & Epithelium & $0.6 \pm 0.5$ & $2.2 \pm 1.3$ & $2.0 \pm 1.2$ & $2.4 \pm 1.1$ & $2.8 \pm 1.4$ \\
\hline & L. propria & $2.6 \pm 1.1$ & $6.2 \pm 2.4$ & $6.6 \pm 2.9$ & $7.6 \pm 2.9$ & $8.6 \pm 2.3$ \\
\hline \multirow[t]{2}{*}{ Uterus } & Epithelium & $0.4 \pm 0.4$ & $0.8 \pm 0.4$ & $1.2 \pm 1.2$ & $2.3 \pm 1.1$ & $1.8 \pm 1.4$ \\
\hline & L. propria & $0.8 \pm 0.3$ & $1.6 \pm 0.6$ & $2.6 \pm 1.8$ & $4.6 \pm 2.8$ & $4.8 \pm 2.2$ \\
\hline
\end{tabular}

Values are given as mean \pm SD. 
tissues ranged from $0.4 \pm 0.4(0 \mathrm{~h})$ to $2.8 \pm 1.4(96 \mathrm{~h})$, and in the lamina propria from $0.8 \pm 0.3(0 \mathrm{~h})$ to $8.6 \pm 2.3$ $(96 \mathrm{~h})$.

\section{Determination of extracellular virus titers (virus production)}

The supernatants of inoculated mucosa explants were collected and titrated at different time points in order to get insights in virus production and shedding. The virus titer curves are given in Figure 1. The virus titers increased over time from $0 \mathrm{~h}$ to $72 \mathrm{hpi}$ in all genital tract tissues. A similar replication was observed for the cervix and uterus explants from animals in luteal and follicular phase. Concerning the vagina mucosa, although there are some differences between the luteal and follicular phase, no significant difference was observed.
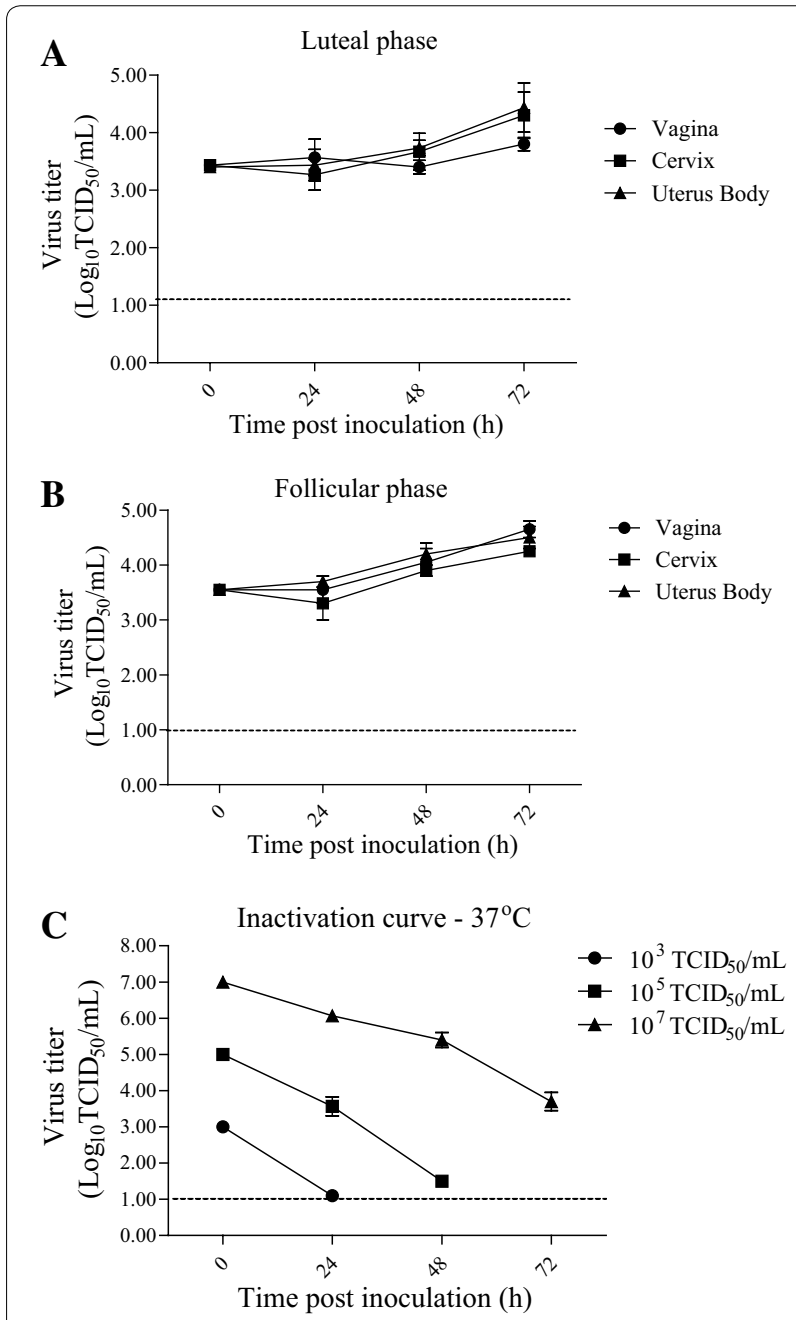

Figure 1 Virus production and shedding of BoHV-4-inoculated genital explants from animals in the luteal (A) and follicular (B) phase and BoHV-4 inactivation curves (C) at $37^{\circ} \mathrm{C}$ in explant medium. The horizontal dotted line represents the detection limit for the titration assay.

\section{BoHV-4 replication pattern}

BoHV-4 positive cells were visible at all collected time points post inoculation. At $24 \mathrm{hpi}$, single positive cells or clusters of a few cells were observed in the epithelium and lamina propria. BoHV-4 positive plaques were detected in the epithelium at 48 and $72 \mathrm{hpi}$ in all the genital tract mucosa explants and at both reproductive cycle phases (Figure 2).

For the luteal phase, the average number of plaques in explants from vagina, cervix and uterus was 4.7, 5.3 and $3.7 / 100$ cryosections at $48 \mathrm{~h}$ and 8,10 and $6.7 / 100$ cryosections at $72 \mathrm{hpi}$, respectively. The BoHV-4-induced epithelial plaques significantly increased in plaque latitude over time in all genital tracts. The viral plaque latitude in the vaginal mucosa increased significantly over time from $48(112.4 \pm 26.6 \mu \mathrm{m})$ to $72 \mathrm{hpi}(178.3 \pm 57.2 \mu \mathrm{m})$, in the cervix mucosa from $48(94.0 \pm 16.5 \mu \mathrm{m})$ to $72 \mathrm{~h}(159.4 \pm 42.1 \mu \mathrm{m})$ and in the uterus from 48 $(99.2 \pm 22.6 \mu \mathrm{m})$ to $72 \mathrm{~h}(145.7 \pm 45.8 \mu \mathrm{m})$. The number of single positive cells increased significantly over time from 0 to $72 \mathrm{hpi}$ in the different parts of genital mucosa. At $72 \mathrm{~h}$, the number of single positive cells in vagina and cervix was 124 and $137 / 10 \mathrm{~mm}^{2}$ mucosa, respectively, which was significantly higher than that in the uterus body $\left(75 / 10 \mathrm{~mm}^{2}\right.$ mucosa).

For the follicular phase, the number of plaques in vagina, cervix and uterus body was $3.3,4.7$ and $3 / 100$ cryosections at $48 \mathrm{~h}$ and $7.7,7$ and 5.3/100 cryosections at $72 \mathrm{hpi}$, respectively. The viral plaque latitude in the vaginal mucosa increased significantly over time from $48(90.7 \pm 16.2 \mu \mathrm{m})$ to $72 \mathrm{hpi}(137.5 \pm 44.0 \mu \mathrm{m})$, in the cervix mucosa from $48(84.3 \pm 20.5 \mu \mathrm{m})$ to $72 \mathrm{~h}$ $(128.4 \pm 38.0 \mu \mathrm{m})$ and in the uterus mucosa from 48 $(82.3 \pm 17.5 \mu \mathrm{m})$ to $72 \mathrm{~h}(130.3 \pm 40.9 \mu \mathrm{m})$. The number of single positive cells in the vagina was $152 / 10 \mathrm{~mm}^{2}$ mucosa, which was significantly higher than that in the uterus $\left(51 / 10 \mathrm{~mm}^{2}\right.$ mucosa) at $24 \mathrm{hpi}$. No significant difference was detected between 48 and 72 hpi.

BoHV-4-induced plaques did not cross the basement membrane $(\mathrm{BM})$ of all tissues and both phases at any time point post inoculation (Figure 3 ).

The number of plaques, plaque latitude and infected cells in the genital tract were compared between animals in the follicular phase and animals in the luteal phase. The number of plaques in the luteal phase was slightly but not significantly higher than that in the follicular phase. The plaque latitude in the luteal phase was also higher but not significantly higher than that in the follicular phase.

\section{BoHV-4 cell tropism at $\mathbf{2 4} \mathrm{h}$ after inoculation}

To better understand the cell tropism of BoHV-4 after inoculation, immunofluorescent double stainings were performed on tissues of the genital tract from the three 

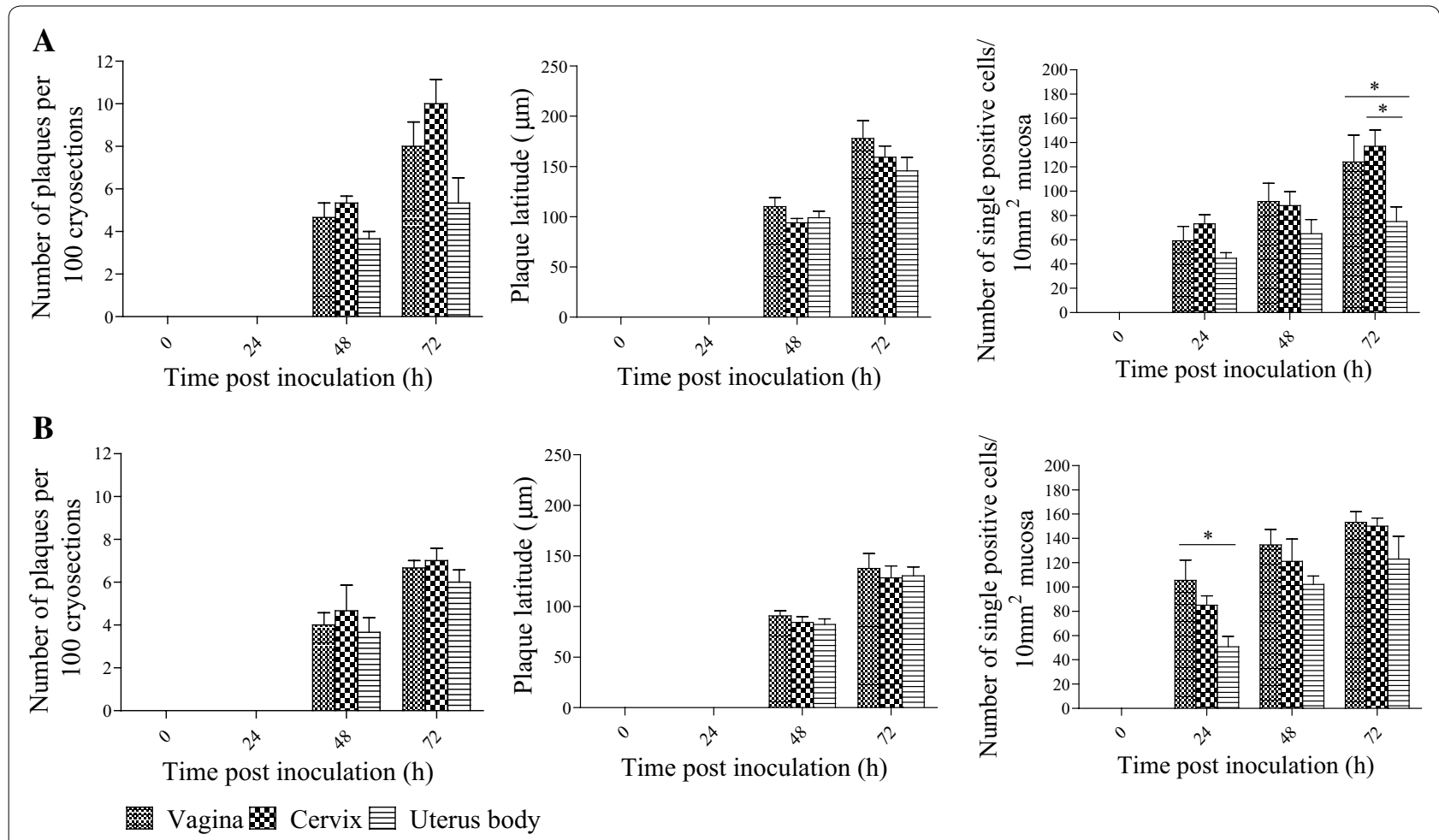

Figure 2 Evolution of plaque number, plaque latitude and number of single BoHV-4 infected cells in both epithelium and lamina propria of genital tract mucosa explants from animals in the luteal (A) and follicular (B) phase. All data represent means + SD of triplicate independent experiments and $P$ values for statistical significance. Asterisks indicate statistically significant differences $(\leq 0.05)$.

different animals in the luteal phase at $24 \mathrm{~h}$ (Figure 4). The majority of infected cells in the epithelium were epithelial cells. The percentage of infected cells that were identified as cytokeratin ${ }^{+}$epithelial cells in vagina, cervix and uterus body was $88.9 \pm 8.6,85.7 \pm 9.8$ and $79.5 \pm 13.3 \%$, respectively. A minority of infected cells were characterized as $\mathrm{CD}_{172 \mathrm{a}^{+}}$monocytic cells in the epithelium. In the lamina propria of vagina, cervix and uterus $83.2 \pm 16.4,71.3 \pm 12.1$ and $79.0 \pm 10.5 \%$ of the infected cells were vimentin ${ }^{+}$and $55.0 \pm 16.2$, $38.7 \pm 22.8$ and $46.2 \pm 21.9 \%$ infected cells were found to be CD172a ${ }^{+}$. Neither BoHV-4 infected B nor T lymphocytes were observed at $24 \mathrm{hpi}$ (Table 2).

\section{BoHV-4 replication in the genital submucosa upon direct injection}

After injection of a mixture of carboxylate-modified microspheres and BoHV-4, an immunofluorescent staining was performed on different genital mucosae from animals in the luteal phase to detect viral replication in the connective tissue at 72 hpi (Figure 5). At the injection site (red beads), plaques of BoHV-4 infected cells (green) were found in the submucosa of vagina, cervix and uterus, which indicates that the virus can easily replicate in the fibrocytes underneath the epithelium.

\section{Discussion}

Until now, a lot of work has already been done on the pathogenesis of gammaherpesviruses. However, data concerning the primary replication and dissemination at the host mucosal entry ports are scarce. Getting insights into how the virus behaves at its primary replication site is important because it can provide methods for prevention and treatment of the viral infection in a rational way. Previously, a murine in vivo model was established which allowed to study the sexual transmission of Murid Herpesvirus 4 (MuHV-4). With this model, Francois et al. were able to demonstrate that MuHV-4 is genitally excreted after latency establishment in intranasally infected female mice. Additionally, efficient virus transmission was observed from females to males following sexual contact and was mediated by the envelope glycoprotein gp150 of MuHV-4 [29, 30]. In this study, tissues from vagina, cervix and uterus body of cows in the luteal and follicular phase were used to establish bovine genital mucosa explants in order to examine the early events of the pathogenesis of a BoHV-4 infection.

Single BoHV-4 infected cells or small clusters were already present at $24 \mathrm{hpi}$ and the majority of the infected cells were of epithelial origin. Only from $48 \mathrm{hpi}$, BoHV-4 positive plaques were visible in the epithelium. BoHV-4 


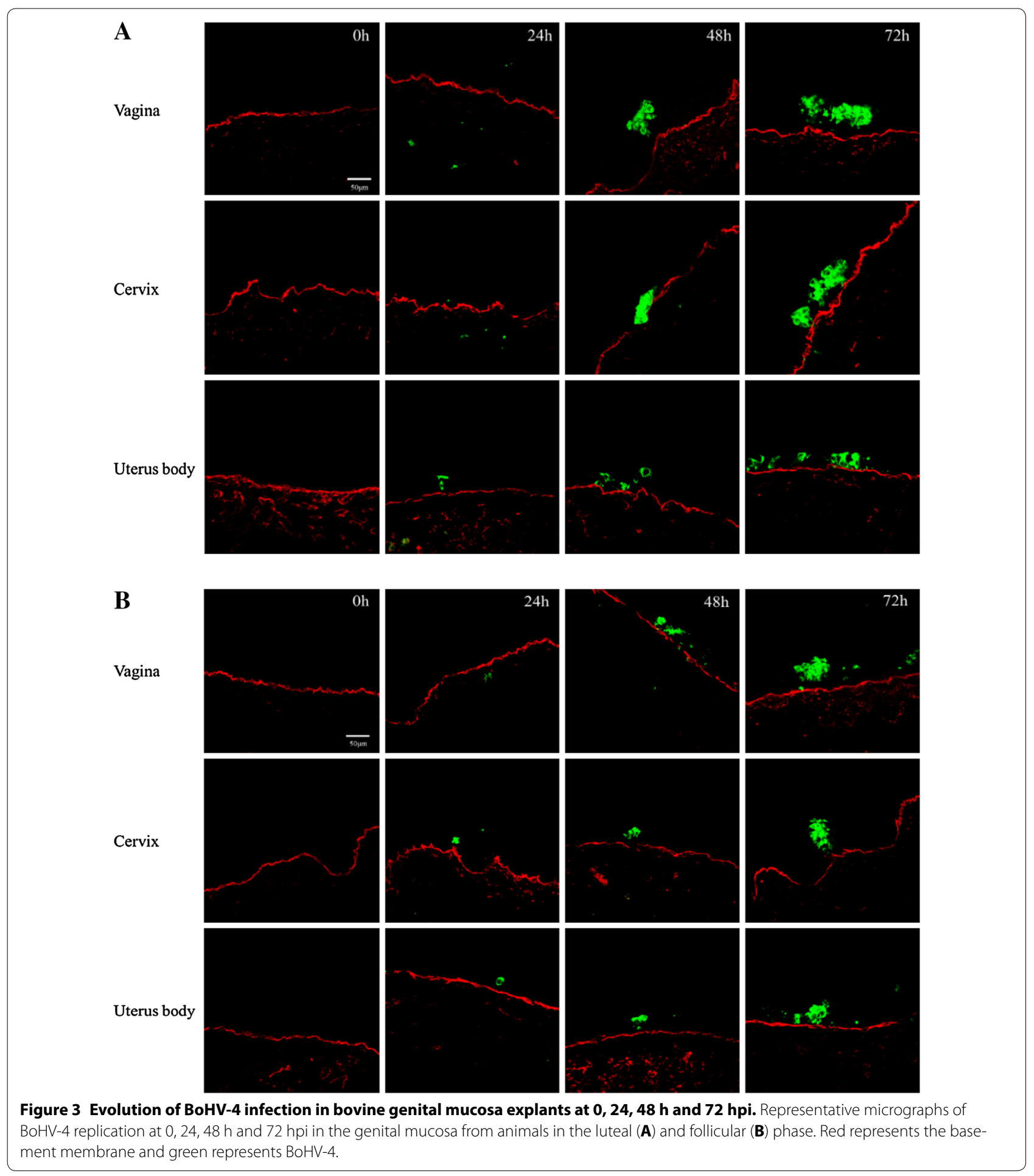

positive plaques did not cross the basement membrane, which is in contrast with the bovine alphaherpesvirus, bovine herpesvirus 1 (BoHV-1). Previous work in our laboratory has shown that BoHV-1 is capable of drilling its way through the basement membrane in an aggressive way. Likewise, other alphaherpesviruses, such as herpes simplex virus-1, pseudorabies virus and feline herpesvirus-1 exhibit also a plaquewise spread through the BM of genital mucosa explants [31-34]. When compared with BoHV-1, BoHV-4 replicated slower in genital explants. 


\section{A}
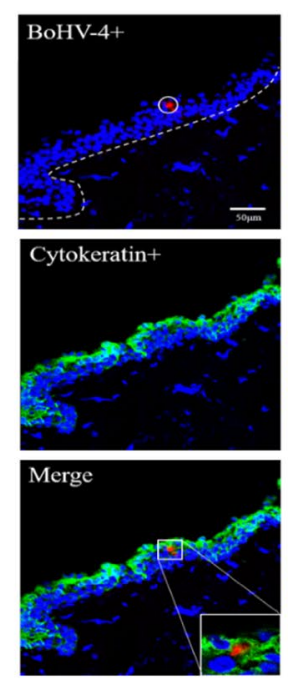

B
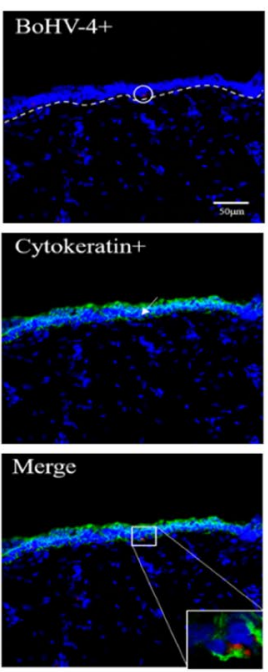

C
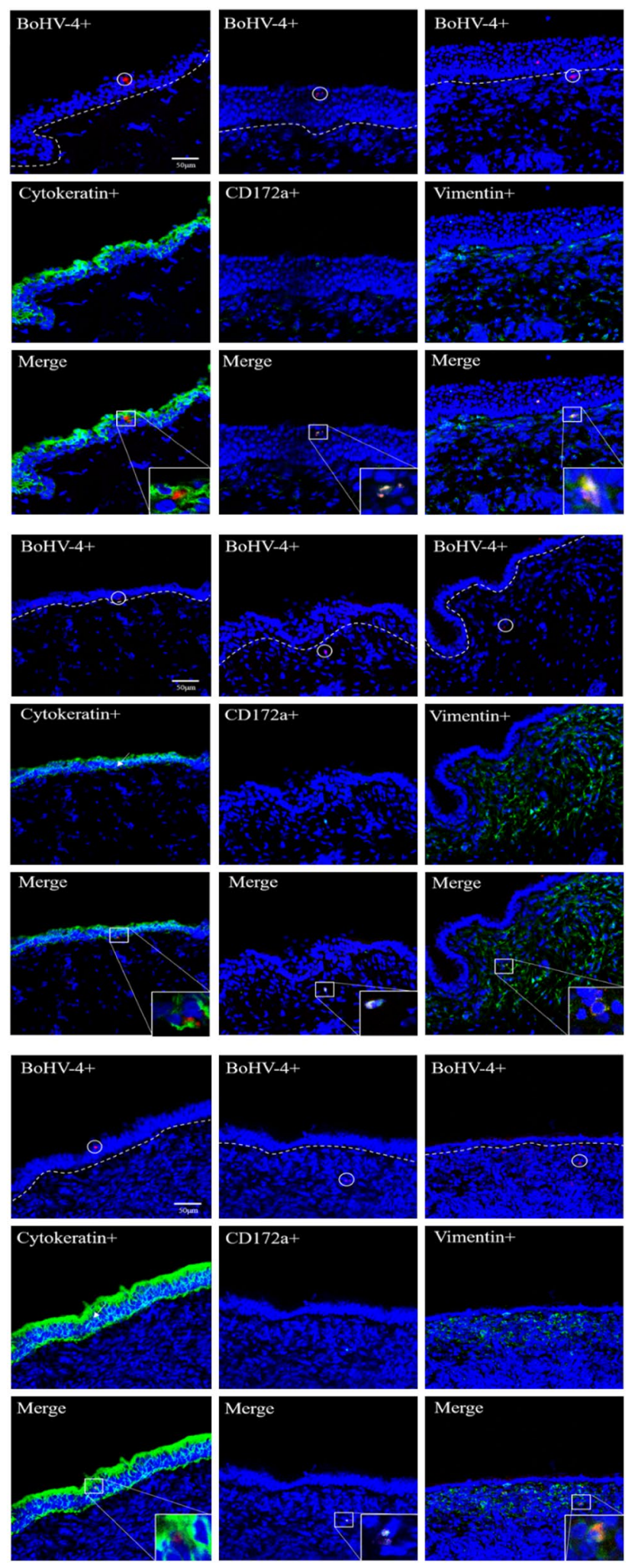

Figure 4 Cell tropism of BoHV-4 at 24 hpi in different parts of the genital mucosa [vagina (A), cervix (B) and uterus (C)] from animals in the luteal phase. The top row shows BoHV-4 positive cells (Alexa fluor ${ }^{\circledR} 594$ ) within the epithelium (dotted line = basement membrane). The middle row shows respectively cytokeratin, CD172a and Vimentin expression (FITC). The bottom row represents merges of the rows above. 
Table 2 Identification of BoHV-4 infected cells at $24 \mathrm{~h}$ post inoculation in genital tissues

\begin{tabular}{|c|c|c|c|c|c|c|}
\hline \multirow[t]{2}{*}{ Tissue } & \multirow[t]{2}{*}{ Zone } & \multicolumn{5}{|c|}{$\begin{array}{l}\text { Marker-positive BoHV-4-infected individual cells in } 20 \text { cryosections/total number of infected cell } \\
(\%)\end{array}$} \\
\hline & & Cytokeratin ${ }^{+}$ & CD172a ${ }^{+}$ & $\lg M^{+}$ & $\mathrm{CD}^{+}$ & Vimentin $^{+}$ \\
\hline \multirow[t]{2}{*}{ Vagina } & Epithelium & $88.9 \pm 8.6$ & $5.1 \pm 3.8$ & $0.0 \pm 0.0$ & $0.0 \pm 0.0$ & $8.3 \pm 2.1$ \\
\hline & L. propria & $0.0 \pm 0.0$ & $55.0 \pm 16.2$ & $0.0 \pm 0.0$ & $0.0 \pm 0.0$ & $83.2 \pm 16.4$ \\
\hline \multirow[t]{2}{*}{ Cervix } & Epithelium & $85.7 \pm 9.8$ & $10.3 \pm 5.4$ & $0.0 \pm 0.0$ & $0.0 \pm 0.0$ & $12.8 \pm 6.1$ \\
\hline & L. propria & $0.0 \pm 0.0$ & $38.7 \pm 22.8$ & $0.0 \pm 0.0$ & $0.0 \pm 0.0$ & $71.3 \pm 12.1$ \\
\hline \multirow[t]{2}{*}{ Uterus } & Epithelium & $79.5 \pm 13.3$ & $15.4 \pm 12.6$ & $0.0 \pm 0.0$ & $0.0 \pm 0.0$ & $10.6 \pm 4.3$ \\
\hline & L. propria & $0.0 \pm 0.0$ & $46.2 \pm 21.9$ & $0.0 \pm 0.0$ & $0.0 \pm 0.0$ & $79.0 \pm 10.5$ \\
\hline
\end{tabular}

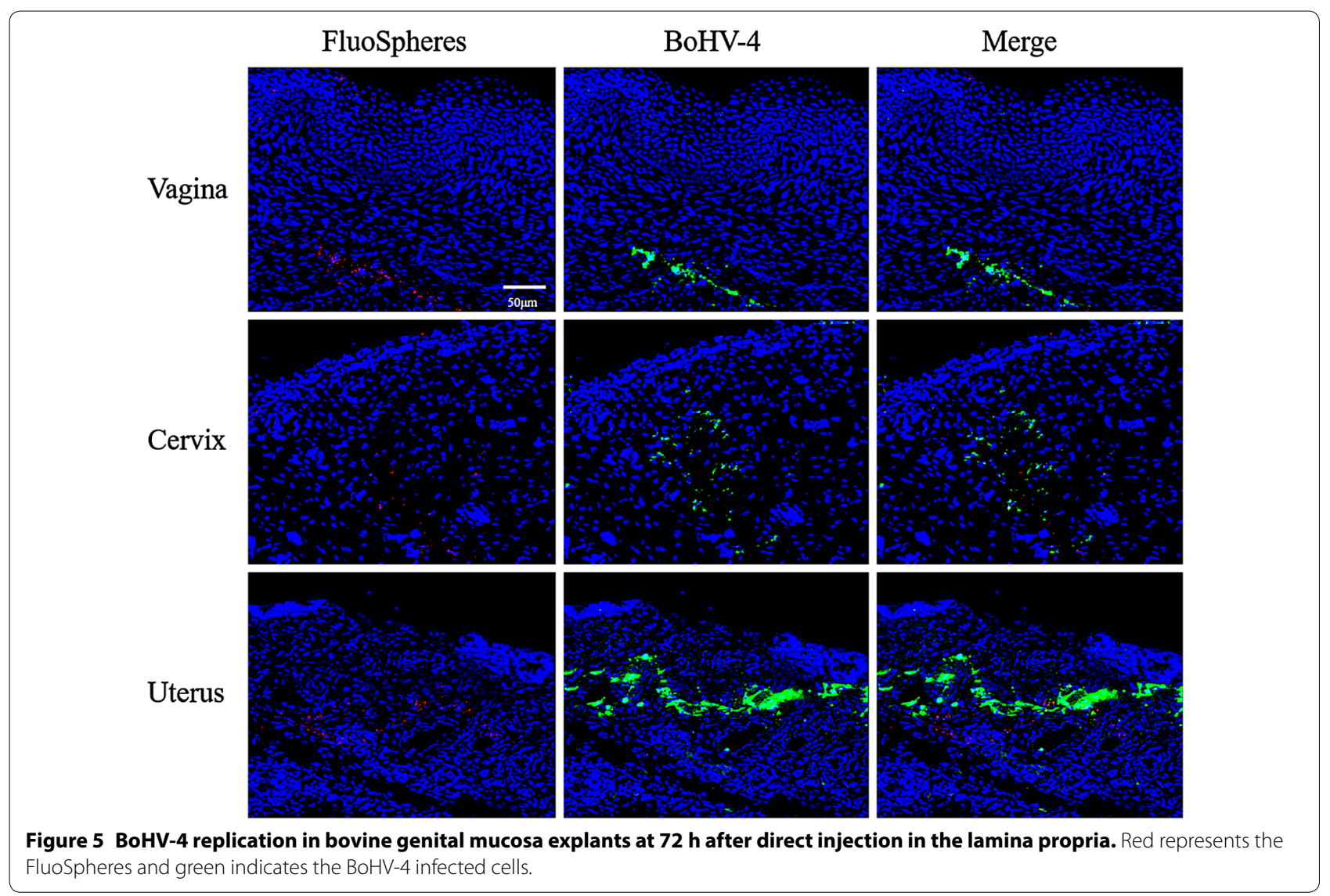

Concerning the BoHV-4 replication in the genital tract of animals in the follicular phase with that of animals in the luteal phase, the number of plaques and plaque latitude in the luteal phase were slightly larger than that in the follicular phase. This might imply that during the luteal phase the genital tract is more susceptible for BoHV-4 than that during the follicular phase. This could be due to a less effective immunity. Indeed, recent studies indicate that progesterone reduces the number of immune cells in the genital tract and inhibit cytokine production by blood mononuclear cells [35-37]. Thus, the higher the progesterone concentration, the stronger the inhibition of the innate immune response. Progesterone is significantly higher during the luteal phase than during other phases of the reproductive cycle, which might explain the more extensive infection of BoHV-4 in genital tract explants as a result of the lower innate immune response. Multiple studies have shown that female sex hormones have a profound effect on the susceptibility to genital herpes infection [29, 38-40]. 
Francois et al. examined the MuHV-4 shedding from the vagina and revealed that this excretion was dependent on the presence of estrogens [29]. In contrast, the presence of progesterone has been shown to increase the susceptibility of the genital tract to herpes simplex virus type 2 (HSV-2) infection [41]; the presence of estrogen decreased the risk of HSV infection in the female genital tract [42-44]. The present study revealed a slight difference in viral infection of explants obtained during the luteal and follicular phase of the menstrual cycle, however, the observed difference was not significant. Because the genital explants were not treated with hormones during the in vitro cultivation, the effects may have been reduced.

The number of single infected cells in the uterus was significant lower than that in the vagina and cervix. This result indicates that BoHV-4 infection in the uterus might be less efficient than in the vagina and cervix. According to the staining results, the number of monocytic cells in vagina and cervix is significantly higher than that in the uterus (data not shown). The smaller population of monocytic cells in the uterus might explain the lower infection.

Although BoHV-4 induced epithelial plaques do not cross the basement membrane, several single positive cells were found in the lamina propria, underneath the basement membrane. To identify which cells are infected, a double staining for cell type and virus was performed. The results showed that the majority of BoHV-4 positive cells were vimentin ${ }^{+}$, of which half of them were CD172a ${ }^{+}$. The other half did not consist of T- and B-lymphocytes. To further investigate whether fibroblasts could be infected, the explants were directly injected with BoHV-4. The results showed that viral plaques were present at the injection sites of lamina propria at $72 \mathrm{hpi}$, which demonstrated that the fibrocytes are fully susceptible for BoHV-4 replication.

Interestingly, Gaspar et al. recently found and proposed that MuHV-4 firstly infects epithelial cells, then myeloid cells and only afterwards B cells by using a homologous mouse model $[45,46]$. B cell infection for MuHV-4 is described to be a late event in the pathogenesis. Indeed, Frederico et al. identified a binding block to B cell infection that was overcome by co-culture with virus propagated in myeloid cells [46]. Nevertheless, in vivo studies have shown that in persistently/latently infected cattle and rabbits especially splenic cells which are located in the marginal zone and belong to the non- $\mathrm{T}$ and non- $\mathrm{B}$ cell compartment, harbor BoHV-4. This indicates that cells of the monocyte/macrophage lineage are the most plausible site of persistent/latent BoHV-4 infection [12,
14, 47-49]. In support of this, Donofrio et al. have shown that cells of the monocyte/macrophage lineage support a BoHV-4 persistent infection [50].

In conclusion, the present study demonstrates that BoHV-4 easily infects the genital tract and may be transmitted in genital secretions. Primary replication starts in epithelial cells. Virus spreads laterally which results in the formation of small viral plaques. Virus is not able to directly cross the basement membrane; instead it hijacks CD172a ${ }^{+}$monocytic cells. When BoHV-4 is produced in connective tissue, fibrocytes may become infected and may eventually lead to pathological processes. To our knowledge, this is the first report describing the invasion mechanism in genital explants. At present, both BoHV-4 and MuHV-4 are accessible experimental models for the hard to study gammaherpesviruses such as human Epstein-Barr virus (EBV) and Kaposi's sarcoma-associated herpesvirus (KSHV).

\section{Additional file}

Additional file 1. TUNEL-staining of vagina, cervix and uterus body explants at $\mathbf{0}$ and $\mathbf{9 6} \mathbf{h}$ of cultivation. The TUNEL assay revealed almost no apoptotic cells (green fluorescence) in vagina, cervix and uterus body at $0 \mathrm{~h}$ and only a low number of positive apoptotic cells at $96 \mathrm{~h}$ of cultivation.

\section{Competing interests}

The authors declare that they have no competing interests.

\section{Authors' contributions}

BY designed and performed the experiments, analyzed the data and helped to draft the manuscript. YL and OBP assisted in sampling. JX and RW participated in writing the manuscript. $\mathrm{HN}$ and $\mathrm{GO}$ conceived and designed the study and helped in writing the manuscript. All authors read and approved the final manuscript.

\section{Acknowledgements}

The authors would like to acknowledge Prof. Dr. Laurent Gillet for providing the BoHV-4 strain V.test and Mab35. Further, we would like to thank Zeger Vandenabeele, Carine Boone, Nele Dennequin and Chantal Vanmaercke for their excellent technical assistance. A special word of appreciation goes to Melanie Bauwens, who performed a numerous amount of virus titration. This work was supported by the China Scholarship Council (201408650005).

\section{Author details \\ 1 Department of Virology, Parasitology and Immunology, Faculty of Vet- erinary Medicine, Ghent University, Salisburylaan 133, B-9820 Merelbeke, Belgium. ${ }^{2}$ Department of Reproduction, Obstetrics and Herd Health, Faculty of Veterinary Medicine, Ghent University, Salisburylaan 133, B-9820 Merelbeke, Belgium.}

\section{Publisher's Note}

Springer Nature remains neutral with regard to jurisdictional claims in published maps and institutional affiliations.

Received: 21 June 2017 Accepted: 6 November 2017

Published online: 28 November 2017 


\section{References}

1. Bartha A, Juhasz M, Liebermann H (1966) Isolation of a bovine herpesvirus from calves with respiratory disease and keratoconjunctivitis. A preliminary report. Acta Vet Acad Sci Hung 16:357-358

2. Reed DE, Langpap TJ, Anson MA (1977) Characterization of herpesviruses isolated from lactating dairy-cows with mammary pustular dermatitis. Am J Vet Res 38:1631-1634

3. Parks JB, Kendrick JW (1973) Isolation and partial characterization of a herpesvirus from a case of bovine metritis. Arch Gesamte Virusforsch 41:211-215

4. Mohanty SB, Hammond RC, Lillie MG (1971) New bovine herpesvirus and its effect on experimentally infected calves. Brief report. Arch Gesamte Virusforsch 33:394-395

5. Smith PC, Young JK, Cutlip RC, Ritchie AE (1972) Bovine herpesvirus associated with a disease of upper respiratory tract of feedlot cattle. J Am Vet Med Assoc 161:1134-1141

6. Reed DE, Langpap TJ, Bergeland ME (1979) Bovine abortion associated with mixed movar 33/63 type herpesvirus and bovine viral diarrhea virus infection. Cornell Vet 69:54-66

7. Frazier KS, Baldwin CA, Pence M, West J, Bernard J, Liggett A, Miller D, Hines ME (2002) Seroprevalence and comparison of isolates of endometriotropic bovine herpesvirus-4. J Vet Diagn Invest 14:457-462

8. Welchman DD, Verkuijl AM, Pepper WJ, Ibata G, King SA, Davidson HM, Mawhinney IC, Banks M (2012) Association of gammaherpesviruses and bacteria with clinical metritis in a dairy herd. Vet Rec 170:207

9. Boerner B, Weigelt W, Buhk HJ, Castrucci G, Ludwig H (1999) A sensitive and specific PCR/Southern blot assay for detection of bovine herpesvirus 4 in calves infected experimentally. J Virol Methods 83:169-180

10. Izumi Y, Tsuduku S, Murakami K, Tsuboi T, Konishi M, Haritani M, Kamiyoshi T, Kimura K, Sentsui H (2006) Characterization of Bovine herpesvirus type 4 isolated from cattle with mastitis and subclinical infection by the virus among cattle. J Vet Med Sci 68:189-193

11. Lete C, Machiels B, Stevenson PG, Vanderplasschen A, Gillet L (2012) Bovine herpesvirus type 4 glycoprotein $L$ is nonessential for infectivity but triggers virion endocytosis during entry. J Virol 86:2653-2664

12. Machiels B, Lete $C$, de Fays $K$, Mast J, Dewals B, Stevenson PG, Vanderplasschen A, Gillet L (2011) The bovine herpesvirus 4 Bo10 gene encodes a nonessential viral envelope protein that regulates viral tropism through both positive and negative effects. J Virol 85:1011-1024

13. Lete C, Palmeira L, Leroy B, Mast J, Machiels B, Wattiez R, Vanderplasschen A, Gillet $L$ (2012) Proteomic characterization of bovine herpesvirus 4 extracellular virions. J Virol 86:11567-11580

14. Machiels B, Lete C, Guillaume A, Mast J, Stevenson PG, Vanderplasschen A, Gillet L (2011) Antibody evasion by a gammaherpesvirus O-glycan shield. PLoS Pathog 7:e1002387

15. Franceschi V, Capocefalo A, Calvo-Pinilla E, Redaelli M, Mucignat-Caretta C, Mertens P, Ortego J, Donofrio G (2011) Immunization of knock-out alpha/beta interferon receptor mice against lethal bluetongue infection with a BoHV-4-based vector expressing BTV-8 VP2 antigen. Vaccine 29:3074-3082

16. Franceschi V, Stellari FF, Mangia C, Jacca S, Lavrentiadou S, Cavirani S, Heikenwalder M, Donofrio G (2014) In vivo image analysis of BoHV-4based vector in mice. PLoS One 9:e95779

17. Palmeira L, Machiels B, Lete C, Vanderplasschen A, Gillet L (2011) Sequencing of bovine herpesvirus 4 V.test strain reveals important genome features. Virol J 8:406

18. Gillet L, Daix V, Donofrio G, Wagner M, Koszinowski UH, China B, Ackermann M, Markine-Goriaynoff N, Vanderplasschen A (2005) Development of bovine herpesvirus 4 as an expression vector using bacterial artificial chromosome cloning. J Gen Virol 86:907-917

19. Donofrio G, Martignani E, Sartori C, Vanderplasschen A, Cavirani S, Flammini CF, Gillet L (2007) Generation of a transposon insertion mutant library for bovine herpesvirus 4 cloned as a bacterial artificial chromosome by in vitro MuA based DNA transposition system. J Virol Methods 141:63-70

20. Donofrio G, Herath S, Sartori C, Cavirani S, Flammini CF, Sheldon IM (2007) Bovine herpesvirus 4 is tropic for bovine endometrial cells and modulates endocrine function. Reproduction 134:183-197

21. Jacca S, Franceschi V, Colagiorgi A, Sheldon M, Donofrio G (2013) Bovine endometrial stromal cells support tumor necrosis factor alpha-induced bovine herpesvirus type 4 enhanced replication. Biol Reprod 88:135
22. Steukers L, Vandekerckhove AP, Van den Broeck W, Glorieux S, Nauwynck HJ (2011) Comparative analysis of replication characteristics of BoHV-1 subtypes in bovine respiratory and genital mucosa explants: a phylogenetic enlightenment. Vet Res 42:33

23. Steukers L, Vandekerckhove AP, Van den Broeck W, Glorieux S, Nauwynck $\mathrm{HJ}$ (2012) Kinetics of BoHV-1 dissemination in an in vitro culture of bovine upper respiratory tract mucosa explants. ILAR J 53:E43-E54

24. Steukers L, Weyers S, Yang X, Vandekerckhove AP, Glorieux S, Cornelissen M, Van den Broeck W, Temmerman M, Nauwynck HJ (2014) Mimicking herpes simplex virus 1 and herpes simplex virus 2 mucosal behavior in a well-characterized human genital organ culture. J Infect Dis 210:209-213

25. Dubuisson J, Thiry E, Bublot M, Sneyers M, Boulanger D, Guillaume J, Pastoret PP (1989) Production and characterization of monoclonal antibodies to bovid herpesvirus-4. Vet Microbiol 19:305-315

26. Dubuisson J, Pastoret PP, Thiry E (1991) Temporal control of bovine herpesvirus type 4 glycoprotein synthesis. J Gen Virol 72:1429-1434

27. Lomonte P, Filee P, Lyaku JR, Bublot M, Pastoret PP, Thiry E (1997) Glycoprotein $\mathrm{B}$ of bovine herpesvirus 4 is a major component of the virion, unlike that of two other gammaherpesviruses, Epstein-Barr virus and murine gammaherpesvirus 68. J Virol 71:3332-3335

28. Luce-Fedrow A, Von Ohlen T, Chapes SK (2009) Ehrlichia chaffeensis infections in Drosophila melanogaster. Infect Immun 77:4815-4826

29. Francois S, Vidick S, Sarlet M, Desmecht D, Drion P, Stevenson PG, Vanderplasschen A, Gillet L (2013) Illumination of murine gammaherpesvirus-68 cycle reveals a sexual transmission route from females to males in laboratory mice. PLoS Pathog 9:e1003292

30. Zeippen C, Javaux J, Xiao X, Ledecq M, Mast J, Farnir F, Vanderplasschen A, Stevenson P, Gillet L (2017) The major envelope glycoprotein of murid herpesvirus 4 promotes sexual transmission. J Virol 91:e00235-e00317

31. Glorieux S, Van den Broeck W, Van der Meulen KM, Van Reeth K, Favoreel HW, Nauwynck HJ (2007) In vitro culture of porcine respiratory nasal mucosa explants for studying the interaction of orcine viruses with the respiratory tract. J Virol Methods 142:105-112

32. Glorieux S, Favoreel HW, Meesen G, de Vos WH, Van den Broeck W, Nauwynck HJ (2009) Different replication characteristics of historical pseudorabies virus strains in porcine respiratory nasal mucosa explants. Vet Microbiol 136:341-346

33. Glorieux S, Favoreel HW, Steukers L, Vandekerckhove AP, Nauwynck HJ (2011) A trypsin-like serine protease is involved in pseudorabies virus invasion through the basement membrane barrier of porcine nasal respiratory mucosa. Vet Res 42:58

34. Li Y, Van Cleemput J, Qiu Y, Reddy VR, Mateusen B, Nauwynck HJ (2015) Ex vivo modeling of feline herpesvirus replication in ocular and respiratory mucosae, the primary targets of infection. Virus Res 210:227-231

35. Bishop CV, Xu F, Molskness TA, Stouffer RL, Hennebold JD (2015) Dynamics of immune cell types within the macaque corpus luteum during the menstrual cycle: role of progesterone. Biol Reprod 93:112

36. Giannoni E, Guignard L, Knaup Reymond M, Perreau M, Roth-Kleiner M, Calandra T, Roger T (2011) Estradiol and progesterone strongly inhibit the innate immune response of mononuclear cells in newborns. Infect Immun 79:2690-2698

37. Alavi-Shoushtari SM, Asri-Rezai S, Abshenas J (2008) A study of the uterine protein variations during the estrous cycle in the cow: molecular weights determination. Anim Reprod Sci 105:302-310

38. Kaushic C (2009) The role of the local microenvironment in regulating susceptibility and immune responses to sexually transmitted viruses in the female genital tract. J Reprod Immunol 83:168-172

39. Kaushic C, Roth KL, Anipindi V, Xiu F (2011) Increased prevalence of sexually transmitted viral infections in women: the role of female sex hormones in regulating susceptibility and immune responses. J Reprod Immunol 88:204-209

40. Brabin $L$ (2002) Interactions of the female hormonal environment, susceptibility to viral infections, and disease progression. AIDS Patient Care STDS 16:211-221

41. Kaushic C, Ashkar AA, Reid LA, Rosenthal KL (2003) Progesterone increases susceptibility and decreases immune responses to genital herpes infection. J Virol 77:4558-4565

42. Bhavanam S, Snider DP, Kaushic C (2008) Intranasal and subcutaneous immunization under the effect of estradiol leads to better protection against genital HSV-2 challenge compared to progesterone. Vaccine 26:6165-6172 
43. Gillgrass AE, Fernandez SA, Rosenthal KL, Kaushic C (2005) Estradiol regulates susceptibility following primary exposure to genital herpes simplex virus type 2, while progesterone induces inflammation. J Virol 79:3107-3116

44. Gillgrass AE, Tang VA, Towarnicki KM, Rosenthal KL, Kaushic C (2005) Protection against genital herpes infection in mice immunized under different hormonal conditions correlates with induction of vagina-associated lymphoid tissue. J Virol 79:3117-3126

45. Gaspar M, May JS, Sukla S, Frederico B, Gill MB, Smith CM, Belz GT, Stevenson PG (2011) Murid herpesvirus-4 exploits dendritic cells to infect B cells. PLoS Pathog 7:e1002346

46. Frederico B, Milho R, May JS, Gillet L, Stevenson PG (2012) Myeloid infection links epithelial and B cell tropisms of Murid Herpesvirus-4. PLoS Pathog 8:e1002935
47. Lopez OJ, Galeota JA, Osorio FA (1996) Bovine herpesvirus type-4 (BHV-4) persistently infects cells of the marginal zone of spleen in cattle. Microb Pathog 21:47-58

48. Osorio FA, Rock DL, Reed DE (1985) Studies on the pathogenesis of a bovine cytomegalo-like virus in an experimental host. J Gen Virol 66:1941-1951

49. Machiels B, Stevenson PG, Vanderplasschen A, Gillet L (2013) A gammaherpesvirus uses alternative splicing to regulate its tropism and its sensitivity to neutralization. PLoS Pathog 9:e1003753

50. Donofrio G, van Santen VL (2001) A bovine macrophage cell line supports bovine herpesvirus-4 persistent infection. J Gen Virol 82:1181-1185

\section{Submit your next manuscript to BioMed Central and we will help you at every step:}

- We accept pre-submission inquiries

- Our selector tool helps you to find the most relevant journal

- We provide round the clock customer support

- Convenient online submission

- Thorough peer review

- Inclusion in PubMed and all major indexing services

- Maximum visibility for your research

Submit your manuscript at www.biomedcentral com/submit 